\title{
Beiträge zur Klimaschwankung im Meere
}

Vorbemerkung. Die Klimaschwankungen wirken sich mannigfach im Meere aus. Betrachtungen hierüber können teils umfangreich sein, teils sich auf Mitteilungen einzelner Tatsachen beschränken. Um letztere, soweit sie in die Deutsche Hydrographische Zeitschrift aufgenommen werden können, nicht als Skizzen im Schrifttum untergehen zu lassen, werden sie künftig unter der Sammelüberschrift "Beiträge zur Klimaschwankung im Meere" zusammengefaßt werden. Hierzu gehören auch folgende Veröffentlichungen, die in den früheren Bänden der Deutschen Hydrographischen Zeitschrift erschienen sind:

Band 1 (1948) S. 220 - Klimaänderung oder Beobachtungsfehler

Band 5 (1952) S. 131 - Normalwerte und Abweichungon der Meerestemperatur bei den nordatlantischen Wetterschiffen

Band 6 (1953) S. 170-Die Abweichungen der Oberflächentemperatur des Ozeans bei den nordatlantischen Wetterschiffen 1951-1953.

Die Schriftleitung

\section{Die nordatlantische Temperaturanomalie in den Jahren 1954 und 1955}

\section{Beitrag}

\section{Von Martin Rodewald}

Zusammenfassung. Die statistische Auswertung der nordatlantischen Wetterschiffsmeldungen ergibt, daß sich die positive Anomalie der Wassertemperaturen im Nordatlantik auch in den Jahren 1954 und 1955 gehalten hat. Sie betrug für das Kollektiv der zehn bzw. (ab Juli 1954) neun Wetterschiffe $+\mathbf{0 , 4 5 ^ { 0 }}$ für $\mathbf{1 9 5 4},+\mathbf{0 , 5 4 ^ { 0 }}$ für $\mathbf{1 9 5 5}$. Sowohl in den Jahreszeiten wie bei den einzelnen Wetterschiffen bestehen aber, wie gezeigt wird, erhebliche Unterschiede der Abweichungen, allerdings weniger dem Vorzeichen als dem Betrage nach. Im Jahrfünftmittel 1951-1955 war das Oberflächenwasser des Nordatlantischen Ozeans $0,55^{0}$ wärmer als normal.

The temperature anomaly in the North Atlantic Ocean during the years 1954 and 1955 (Summary). The statistical evaluation of the records from the North Atlantic weather ships shows that the positive anomaly of sea temperature in the North Atlantic Ocean has been maintained throughout the years 1954 and 1955. The anomaly for the total of the ten or nine weather ships respectively

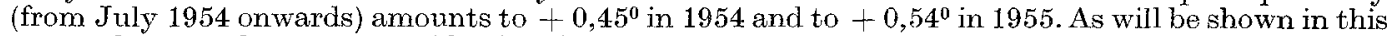
paper, there are, however, considerable differences in the departures from the normal, due to seasonal infuences and conditions near the individual weather ships. These differences bear, however, less on the sign than on the amount of the departure. During the five years' period from 1951 to 1955 the mean surface temperatures of the North Atlantic Ocean were found to be by $0,55^{\circ}$ higher than normal.

I'anomalie de la température de l'eau dans l'Atlantique Nord pendant les années de 1954 et de 1955 (Résumé). L'évaluation statistique des températures mesurées à bord des frégates météorologiques montre que l'anomalie positive des températures de l'eau de l'Atlantique Nord s'est maintenue pendant les années de 1954 et de 1955 . Cette anomalie s'élève à $+0,45^{\circ}$ en 1954 et à $+0,54^{\circ}$ en 1955 pour l'ensemble de dix ou respectivement de neuf (à partir de juillet 1954) frégates météorologiques de l'Atlantique Nord. Comme on le montrera dans le travail actuel, les écarts à la normale se distinguent sensiblement entre elles ce qui est dû aux influences saisonnières et aux conditions rencontrées près des frégates météorologiques individuelles. Ces différences concernent la grandeur des écarts plutôt que le signe. Pendant les cinq années de 1951 à 1955 la température moyenne de la surface de l'Atlantique Nord était supérieure à sa valeur normale de $0,55^{\circ}$.

$I^{n}$ früheren Heften dieser Zeitschrift (M. Rodewald [1952a, 1953]) wurden vom Verfasser die Abweichungen der Oberflächentemperatur des Ozeans bei den zehn nordatlantischen Wetterschiffen bis zum Jahre 1953 mitgeteilt und diskutiert.

Als Ergänzung dazu seien im folgenden die Verhältnisse in den Jahren 1954 und 1955 dargestellt. Leider ist die Wetterschiffsposition $H$ (etwa $36^{\circ} \mathrm{N}, 70^{\circ} \mathrm{W}$ ) aufgelöst worden und von Juli 1954 an nicht mehr besetzt gewesen, so daß seit dieser Zeit nur neun Positionen mit Werten vertreten sind. Die Bildung der Monatsmittel und ihrer Abweichungen vom Normalwert erfolgte in derselben Weise wie in der ersten Mitteilung angegeben. Eine größere Extrapolation betraf nur das Wetterschiff $\mathrm{K}$ im Monat Mai 1954, das nur mit etwa einem Monatsdrittel an Messungen vertreten war.

Die Tabellen 1 und 2 geben die Monatsanomalien der Jahre 1954 und 1955 für die einzelnen Wetterschiffe, sowie die mittleren Anomalien des Wetterschiffskollektivs und des Jahres, dazu eine U̇bersicht der Vorzeichen-Verteilung. 